\title{
Expression of ATP-sensitive potassium channels in human pregnant myometrium
}

\author{
Chen Xu', Xingji You', Lu Gao ${ }^{1}$, Lanmei Zhang ${ }^{2}$, Rong Hu${ }^{3}$, Ning Hui ${ }^{3}$, David M Olson ${ }^{4}$, Xin $\mathrm{Ni}^{1 *}$
}

\begin{abstract}
Background: Potassium channels play critical roles in the regulation of cell membrane potential, which is central to the excitability of myometrium. The ATP-sensitive potassium (KATP) channel is one of the most abundant potassium channels in myometrium. The objectives of this study were to investigate the protein expression of KATP channel in human myometrium and determine the levels of KATP channel in lower and upper segmental myometrium before and after onset of labour.
\end{abstract}

Methods: Both lower segmental (LS) and upper segmental (US) myometrial biopsies were collected at cesarean section from pregnant women not-in-labour (TNL) or in-labour (TL) at term. Protein expression level and cellular localization of four KATP channel subunits in US and LS myometrium were determined by Western blot analysis and immunohistochemistry, respectively. The contractile activity of myometrial strip was measured under isometric conditions.

Results: Four KATP channel subunits, namely Kir6.1, Kir6.2, SUR1 and SUR2B were identified in pregnant myometrium. While found in vascular myocytes, these subunits appear to be preferentially expressed in myometrial myocytes. Diazoxide, a KATP channel opener, inhibited the spontaneous contractility of pregnant myometrium, suggesting that the KATP channels are functional in human pregnant myometrium. Diazoxide was less potent in TL strips than that in TNL strips. Interestingly, expression of SUR1 was greater in TL than TNL tissues, although no differences were found for SUR2B in these two tissues. For both lower and upper segmental myometrium, Kir6.1 and Kir6.2 were less in TL compared with TNL tissues.

Conclusions: Functional KATP channels are expressed in human pregnant myometrium. Down-regulation of Kir6.1 and Kir6.2 expression in myometrium may contribute to the enhanced uterine contractility associated with the onset of labour.

\section{Background}

Human myometrium undergoes dramatic physiological and biochemical changes during pregnancy and parturition. Myometrium remains in a relatively quiescent state during most time of pregnancy, but it develops the highly organized and powerful contraction with onset of labour [1]. The molecular mechanisms underlying the transit of myometrium from a state of relative quiescence to the activated and contractile state are not fully understood. However, it has been proposed that this process is associated with coordinated expression of various proteins including the receptors of uterotonic and uterorelaxant factors, GAP junction and ion channels [1-3].

\footnotetext{
* Correspondence: nixin@smmu.edu.cn

'Department of Physiology, Second Military Medical University, Shanghai 200433, China

Full list of author information is available at the end of the article
}

Potassium channels play critical roles in the regulation of cell membrane potential, which is central to the excitability and contractility of myometrium $[4,5]$. The opening of these channels results in $\mathrm{K}^{+}$efflux, causing the membrane potential to closer to $\mathrm{K}^{+}$equilibrium potential, and thereby reducing excitability and contractility of the smooth muscle cells. Thus, the changes in the expression or activity of $\mathrm{K}^{+}$channels can translate into a change in excitability and contractility of myometrium.

The ATP-sensitive potassium ( $\mathrm{K}_{\mathrm{ATP}}$ ) channel is one of the most abundant potassium channels and likely contributes to the resting membrane potential in smooth muscle tissues [6]. The channel comprises heteromultimers of an inwardly rectifying $\mathrm{K}^{+}$channel (Kir) and a modulatory sulphonylurea receptor subunit (SUR) which is responsible for the ATP sensitivity and pharmacological properties [7-10]. Functional studies indicated that $\mathrm{K}_{\mathrm{ATP}}$

\section{Biomed Central}


channel plays a role in the regulation of myometrial activity during pregnancy [11-13]. The $\mathrm{K}_{\mathrm{ATP}}$ channel mRNA has been identified in pregnant myometrium. Chien et al [14] had shown the transcripts of $K_{\text {ATP }}$ channel subunits in pregnant rat myometrium. Curley and coworkers detected the mRNA expression of Kir 6.1, Kir 6.2, SUR1 and SUR2B in human pregnant myometrium and demonstrated that Kir6.1/SUR2B may be the predominant isoform of $\mathrm{K}_{\mathrm{ATP}}$ channel in human myometrium [15]. However, no information is available on the protein expression of $\mathrm{K}_{\mathrm{ATP}}$ channel subunits in myometrium.

It seems that there is a functional regionalization in human myometrium during pregnancy and labour. The upper segment (US) region of the uterus maintains a relaxatory phenotype to accommodate the growing fetus throughout most of gestation and then at labour contracts to cause expulsion of the fetus, while the lower segment (LS) region is supposed to display a contractile phenotype during most time of pregnancy and at onset of labour transforms into a relaxatory phenotype, thereby allowing passage of fetus [16]. Current studies regarding the expression of $\mathrm{K}_{\mathrm{ATP}}$ channel in human myometrium are restricted to LS [15]. There is a lack of literature addressing the changes in the expression of $\mathrm{K}_{\mathrm{ATP}}$ channel in the different region of uterus during pregnancy and labour. Exploring this issue will expand our knowledge regarding the mechanisms controlling human parturition.

The objectives of study are to confirm the expression of $\mathrm{K}_{\text {АтP }}$ channel subunits at protein level in human pregnant myometrium and examine whether the expression of these proteins in different region of uterus is changed during labour.

\section{Methods}

\section{Tissue collection}

The lower uterine segmental myometrial tissues from pregnant women were collected in Changhai Hospital, the affiliated hospital of Second Military Medical University. Upper uterine segmental myometrial tissues from pregnant women were collected in Navy General Hospital, the teaching hospital of Second Military Medical University. Approval of this study was granted by human ethic committee of Changhai Hospital, Navy General Hospital as well as human ethic committee of Second Military Medical University. Written informed consent was obtained from each participant.

LS myometrial biopsies were collected at cesarean section from the pregnant women at term pregnancy $(37-42 \mathrm{wk})$ prior to the onset of labour (TNL, $\mathrm{n}=13$ ) or during labour (TL, $\mathrm{n}=13$ ). Paired US and LS tissues were collected from the pregnant women at term pregnancy (37-42 wk) before the onset of labour (TNL, $\mathrm{n}=$ 7) or during labour ( $T L, n=4)$. Labour was defined as regular contractions ( $<5$ min apart) and cervical dilation $(>3 \mathrm{~cm})$ without oxytocin or prostaglandin administration. Indications for cesarean section included breech presentation, placenta previa, previous cesarean section, cephalopelvic disproportion, failure of labour to progress, fetal distress, or maternal request. Women who had the evidence of underlying disease, such as hypertension, diabetes, preeclampsia, intrauterine growth restriction, etc, were not included in this study. LS uterine samples were removed from the upper margin of the uterine incision after delivery of the fetus and placenta. US samples were taken just below the fundus through the upper incision by using biopsy forceps. Collected samples were then frozen immediately in liquid nitrogen and stored at $-80^{\circ} \mathrm{C}$. For immunohistochemical analysis, the biopsies were placed in $10 \%$ phosphate buffered formalin. Tissues for contractility study were immediately placed in phosphate-buffered saline on ice and transported to the laboratory.

\section{Immunohistochemistry}

Immunohistochemistry was carried out as described previously $[17,18]$. Briefly, paraffin sections $(5 \mu \mathrm{m})$ were cut, rehydrated and microwaved in citric acid buffer to retrieve antigens. Immunohistochemistry were performed with the Histostain-SP kit (Zymed, San Franscisco, CA), which uses a biotinylated second antibody, a horseradish peroxidase-streptavidin conjugate, and a substrate-chormogen mixture to demonstrate antigen in the tissue. The specific antibodies for Kir 6.1 (sc-11224), Kir 6.2 (sc-11228), SUR1 (sc-5789) and SUR2B (sc-5793) were purchased from Santa Cruz Biotechnology (Santa Cruz Biotechnology, Inc. Santa Cruz, CA). The tissue sections were incubated with $3 \% \mathrm{H}_{2} \mathrm{O}_{2}$ to inhibit endogenous peroxidases and then incubated with $10 \%$ rabbit serum for 30 min to block nonspecific antibody binding. The tissue sections were then incubated with the specific antibodies (1:500) for $24 \mathrm{hr}$ at $4 \mathrm{C}$. The bound antibodies were detected with the biotinstreptavidin-peroxidase system (UltraSensitive-SP-kit, MaiXin Biotechnology, Fuzhou, China) using diaminobenzidine (Sigma-Aldrich) as chromogen. Counterstaining was performed with hemalum. Mouse antihuman smooth muscle $\alpha$-actin-specific monoclonal antibody (Dako Inc. Carpinteria, CA) was used to stained the smooth muscle cells. Negative controls were performed by substituting primary antibody with a normal serum in same dilution as well as preabsorption of the primary antibody with a tenfold excess of the blocking peptides (Kir 6.1: sc-11224 P; kir6.2:sc-11228 P; SUR1: sc-5789 P; SUR2B: sc-5793 P).

\section{Isometric recording of myometrium contraction}

The myometrium tissues (about $3 \times 3 \times 10 \mathrm{~mm}$ pieces) were mounted on parallel wires and placed in a $30 \mathrm{ml}$ organ bath filled with Krebs solution maintained 
at $37^{\circ} \mathrm{C}$, bubbled with a gas mixture $\left(95 \% \mathrm{O}_{2}-5 \% \mathrm{CO}_{2}\right)$. The contractile activity was measured isometrically by a tension transducer, followed by computerized recording and processing (MedLab, Nanjing, China). Each strip of myometrium was set up under an initial tension of $1 \mathrm{~g}$ and allowed to equilibrate for $90 \mathrm{~min}$, and the Kreb's solution was changed every $30 \mathrm{~min}$. After the regular contractions (regular in frequency and strength) were established, diazoxide (Sigma-Aldrich, St. Louis,MO) was added in a cumulative manner to the bath at $30 \mathrm{~min}$ intervals. Appropriate controls (incubation with solvents) were run under similar experimental conditions in rings of uterus obtained from the same woman. Only one concentration-response curve was performed in each uterine strip. The responses were quantified by the amplitude and frequency of the contractions as well as integration of the area under each contractile record (AUC) using software written specifically for this purpose. The AUC was measured from the basal tension over a 10-min period after each stimulus. The effects were evaluated by comparing the experimental responses with the controls (set as 100\%). The data of contractility were presented as percentage of control (\% of control).

\section{Western Blot Analysis}

Approximately $50 \mathrm{mg}$ of human myometrial tissue was homogenized in ice-cold lysis buffer consisting of $60 \mathrm{mM}$ Tris- $\mathrm{HCl}, 2 \%$ sodium dodecyl sulfate (SDS), $10 \%$ sucrose, $2 \mathrm{mM}$ phenylmethylsulfonyl fluoride (Merck, Darmstadt, Germany), $1 \mathrm{mM}$ sodium orthovanadate, $10 \mu \mathrm{g} / \mathrm{ml}$ aprotinin (Bayer, Leverkusen, Germany). Lysates were then quickly ultrasonicated in ice bath, boiled $5 \mathrm{~min}$ at $95 \mathrm{C}$ and centrifuged. The supernatants were collected and stored at $-80 \mathrm{C}$. Protein concentrations were measured using a modified Bradford assay. The samples were diluted in sample buffer ( $250 \mathrm{mM}$ Tris- $\mathrm{HCl}$ (pH 6.8), containing $4 \%$ SDS, $10 \%$ glycerol, $2 \% \beta$-mercaptoethanol, and $0.002 \%$ bromophenol blue) and boiled for another $5 \mathrm{~min}$. Aliquots of proteins were separated by SDS-PAGE $(10 \%)$ and subsequently transferred to nitrocellulose membranes by electroblotting. The membrane was blocked in $5 \%$ skim milk powder in $0.1 \%$ Tris-buffered saline/Tween 20 (TBST) at room temperature for $2 \mathrm{~h}$, and then was incubated with antibodies raised against Kir 6.1, Kir6.2, SUR1 and SUR2B (1:500) at 4 C overnight. After another three washes with TBST, the filters were incubated with a secondary horseradish peroxidaseconjugated IgG (1:1000) for $1 \mathrm{~h}$ at room temperature and further washed for $30 \mathrm{~min}$ with TBST. Immunoreactive proteins were visualized using the enhanced chemiluminescence Western blotting detection system (Santa Cruz). The light-emitting bands were detected with X-ray film. To control sampling errors, the expression of $\beta$-actin was also detected. The resulting band intensities were quantitated by using an image scanning densitometer (Furi Technology, Shanghai, China). Peak count values were expressed as densitometric units. The ratio of band intensities to $\beta$-actin was obtained to quantify the relative protein expression level of Kir 6.1, Kir6.2, SUR1 or SUR2B.

\section{Statistical analysis}

The data are presented as mean \pm SEM. All data were tested for homogeneity of variance by Bartlett's test. The results indicated that the data were normally distributed. Individual comparisons were made by one-way ANOVA followed by LSD-t test. P-value of $<0.05$ was considered to be significant.

\section{Results}

\section{Expression and localization of KATP channel subunits in} pregnant human myometrium

Immunohistochemistry revealed that positive immunoreactivity for Kir6.1, Kir6.2, SUR1 and SUR2B subunit was identified in human pregnant myometrium. These subunits of $\mathrm{K}_{\mathrm{ATP}}$ channel were localized to uterine myocytes. Smooth muscle cells lining blood vessel were also positively stained for these proteins. Immunoreactivity was abolished when the antibody was preabsorbed with excess peptide, thereby confirming the specificity of the antibodies (Figure 1).

\section{The effect of $K_{\text {ATP }}$ channel opener on spontaneous contractility of myometrium strip}

To confirm the $\mathrm{K}_{\mathrm{ATP}}$ channel activity in pregnant myometrium, we examined the effect of diazoxide, an opener of $\mathrm{K}_{\mathrm{ATP}}$ channels, on spontaneous contractility of LS strips that were obtained from pregnant women who were undergoing labour or not undergoing labour at term. As shown in Figure 2A \&2B, treatment of strips with a cumulative increase in concentrations of diazoxide inhibited the phasic contractions. At $10^{-4} \mathrm{~mol} / \mathrm{L}$, diazoxide completely suppressed the spontaneous contractions.

We then compared the effects of diazoxide in nonlabouring and laboring myometrial strips. As shown in Figure $2 \mathrm{C}-\mathrm{D}$, the effects of diazoxide on contractility were decreased in TL strips compared with that in TNL strips. The IC50 values of diazoxide in TL group were significantly different from that in TNL group $\left(1.80 \times 10^{-4} \pm\right.$ $5.46 \times 10^{-6} \mathrm{~mol} / \mathrm{L}$ versus $1.06 \times 10^{-4} \pm 4.37 \times 10^{-5} \mathrm{~mol} / \mathrm{L}$ for amplitude, $P<0.05, \mathrm{n}=3 ; 3.24 \times 10^{-5} \pm 2.68 \times$ $10^{-5} \mathrm{~mol} / \mathrm{L}$ versus $6.83 \times 10^{-6} \pm 1.27 \times 10^{-6} \mathrm{~mol} / \mathrm{L}$ for frequency, $P<0.05 ; \mathrm{n}=3$ ).

\section{The expression of $\mathrm{K}_{\mathrm{ATP}}$ channel subunits in pregnant myometrium before and during labour}

Western blotting analysis detected a band of $51 \mathrm{kDa}$ for Kir6.1, 40 kDa for Kir6.2, 150 kDa for SUR1 and 150 kDa 


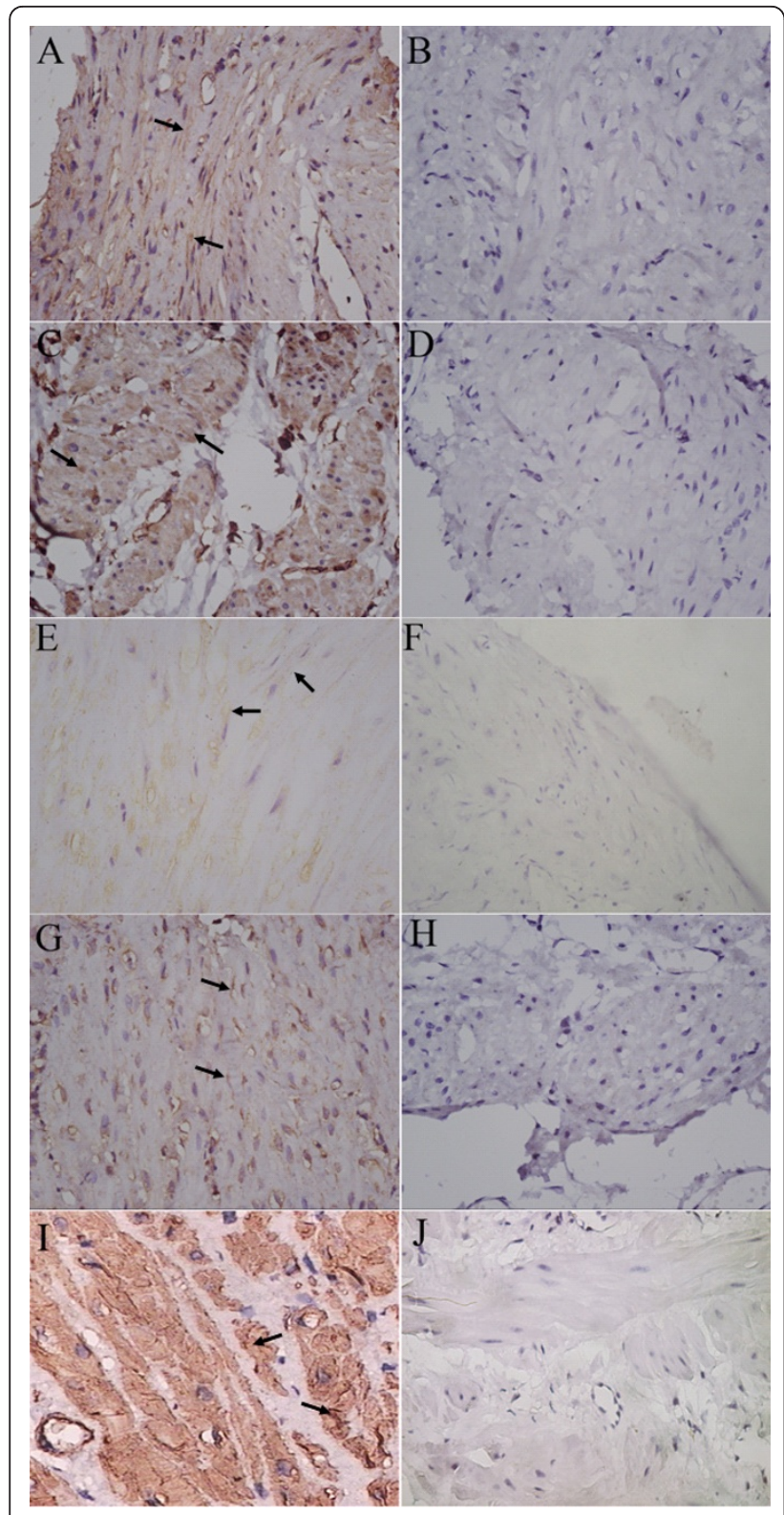

Figure 1 The expression of $\mathrm{K}_{\text {ATP }}$ channel subunits was identified by immunohistochemistry in pregnant human myometrium.

$A$, representative section immunostained with the specific antibody against Kir6.1. B, negative control. The primary antibody was substituted by Kir6.1 preabsorption antibody. C, representative section of positive staining for Kir6.2. D, negative control section. The primary antibody was substituted by Kir6.2 preabsorption antibody. $E$, representative section stained with the specific antibody against SUR1. F, negative control section. The primary antibody substituted by SUR1 preabsorption antibody. $G$, the section immunostaied with SUR2B antibody. $\mathrm{H}$, negative control section. The primary antibody was substituted by SUR2B preabsorption antibody. I, the section stained with $\alpha$-actin antibody. J, negative control. The primary antibody was substituted by normal serum. Arrow: positive staining in myometrium smooth muscle cells. Original magnification $\times 400$. for SUR2B in pregnant human myometrium. To give an overall expression profile in the US and LS, the paired expression values from all the patients were combined. When the overall expression level of each protein was compared in the pregnant US and LS samples, there were no significant differences in the levels of each protein between US and LS myometrium (Figure 3).

In lower segmental myometrium samples, the level of Kir6.1 was significantly decreased in TL group compared with TNL group (TL versus TNL, $P<0.01$ ). Kir6.2 expression was also significantly down-regulated during labour (TL versus TNL, $P<0.05$ ). The expression of SUR1 was increased in TL group compared with TNL group $(P<0.01)$. No marked difference in SUR2B level was observed between TNL and TL groups (Figure 4).

In upper segmental biopsies, both of Kir6.1 and Kir6.2 expression were significantly down-regulated in TL group compared with TNL group (TL versus TNL, $P<$ 0.05; Figure 5). No significant difference in SUR1 and SUR2B levels was observed between TNL and TL groups.

\section{Discussion}

Some functional studies suggest the $\mathrm{K}_{\mathrm{ATP}}$ channel activity in human myometrium by using the opener and blockers of $K_{\text {ATP }}$ channels [19-22]. The $K_{\text {ATP }}$ channels have been identified in human myometrium, but at mRNA level [15]. Considering the fact that not all mRNA is translated to protein due to mRNA instability, it is important to know the protein expression of $\mathrm{K}_{\mathrm{ATP}}$ subunits during pregnancy and labour. The present study demonstrated, for the first time, the protein expression of Kir6.1, Kir6.2, SUR1 and SUR2B subunits of $K_{\text {ATP }}$ channels in human myometrium and showed the localization of these four subunits in myometrium.

The $\mathrm{K}_{\mathrm{ATP}}$ channel subunits were also identified in smooth muscle layer of uterine vasculature in the pregnant myometrium. Because the proportion of vasculature smooth muscle is very small in the myometrial samples, the protein level of $\mathrm{K}_{\mathrm{ATP}}$ channel subunits can reflect the expression of this channel in uterine smooth muscle.

Different combinations of Kir and SUR isoforms/variants yield tissue-specific $\mathrm{K}_{\mathrm{ATP}}$ channel subtypes with different features and distinct functional properties. For instance, SUR1-Kir6. 2 forms the pancreatic $\beta$-cell $\mathrm{K}_{\mathrm{ATP}}$ channel [23,24], and SUR2A-Kir6.2 forms the cardiac $\mathrm{K}_{\text {ATP }}$ channel [25]. Two types of smooth muscle-type $\mathrm{K}_{\mathrm{ATP}}$ channels have been cloned and identified, namely Kir6.2-SUR2B channels and Kir6.1-SUR2B channels $[10,26]$. Some studies have demonstrated the presence of SUR1 subunit in smooth muscle tissues including pig 


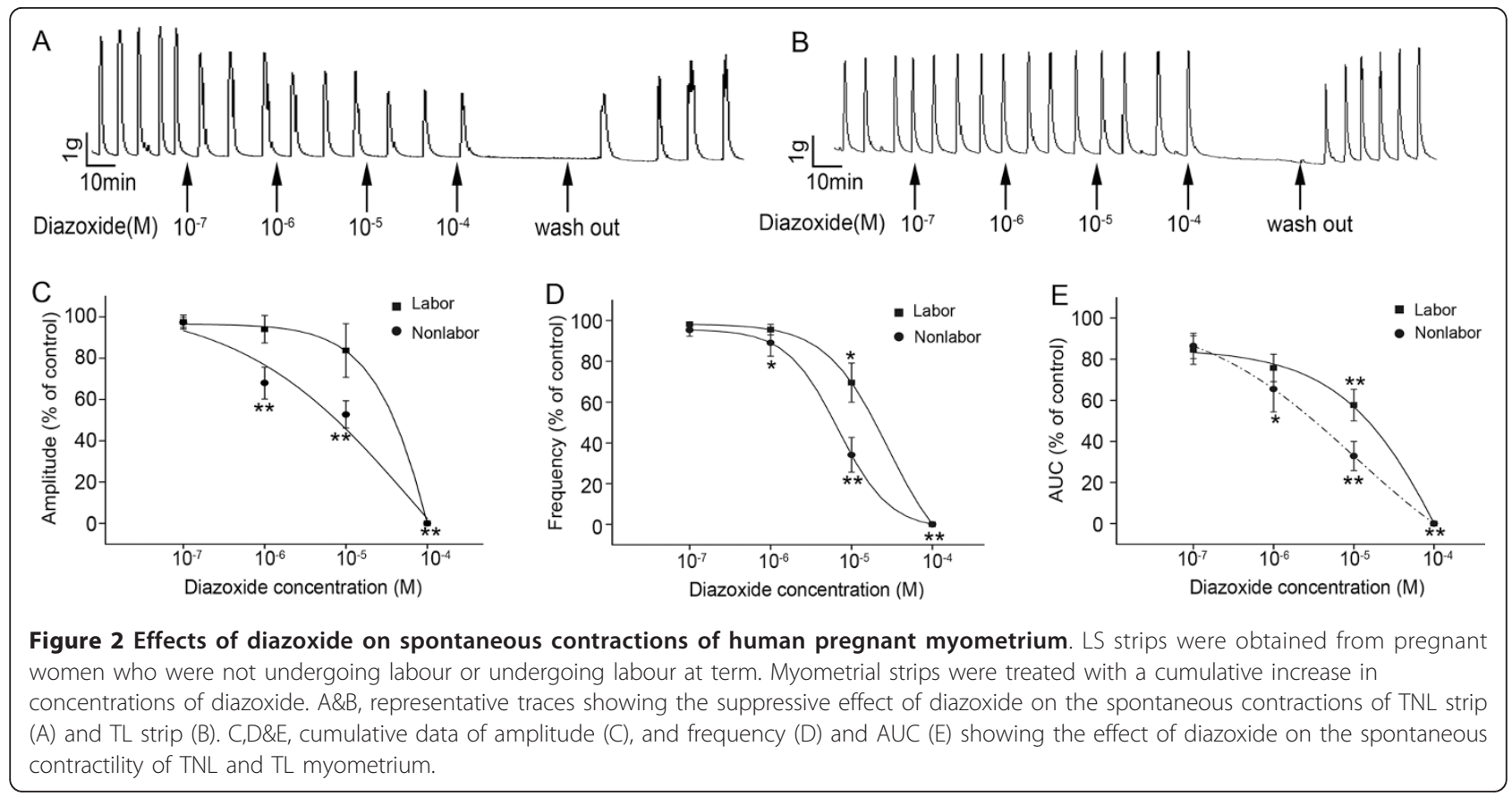

urethra, rat and human myometrium [15,27-29]. Curley and coworkers' study indicated that Kir6.1/SUR2B is the predominant isoforms of $\mathrm{K}_{\mathrm{ATP}}$ channel in human myometrium although they detected the transcript of Kir6.2 and SUR1 [15]. Our present study also found the protein

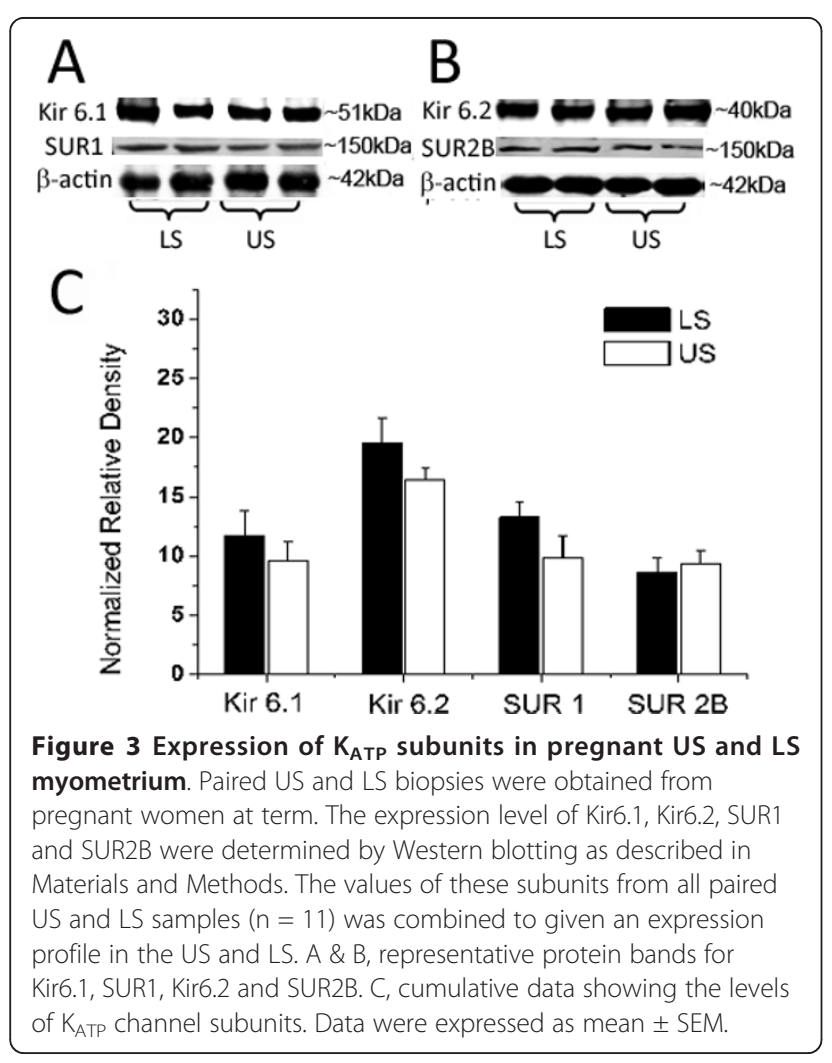

expression of Kir6.1, Kir6.2, SUR1 and SUR2B subunits in human pregnant myometrium. Diazoxide, a $K_{\mathrm{ATP}}$ opener, is known to activate $\mathrm{K}_{\mathrm{ATP}}$ channels containing SUR1 or SUR2B but not those containing SUR2A $[8,10]$ and has been shown to be able to inhibit the contractility

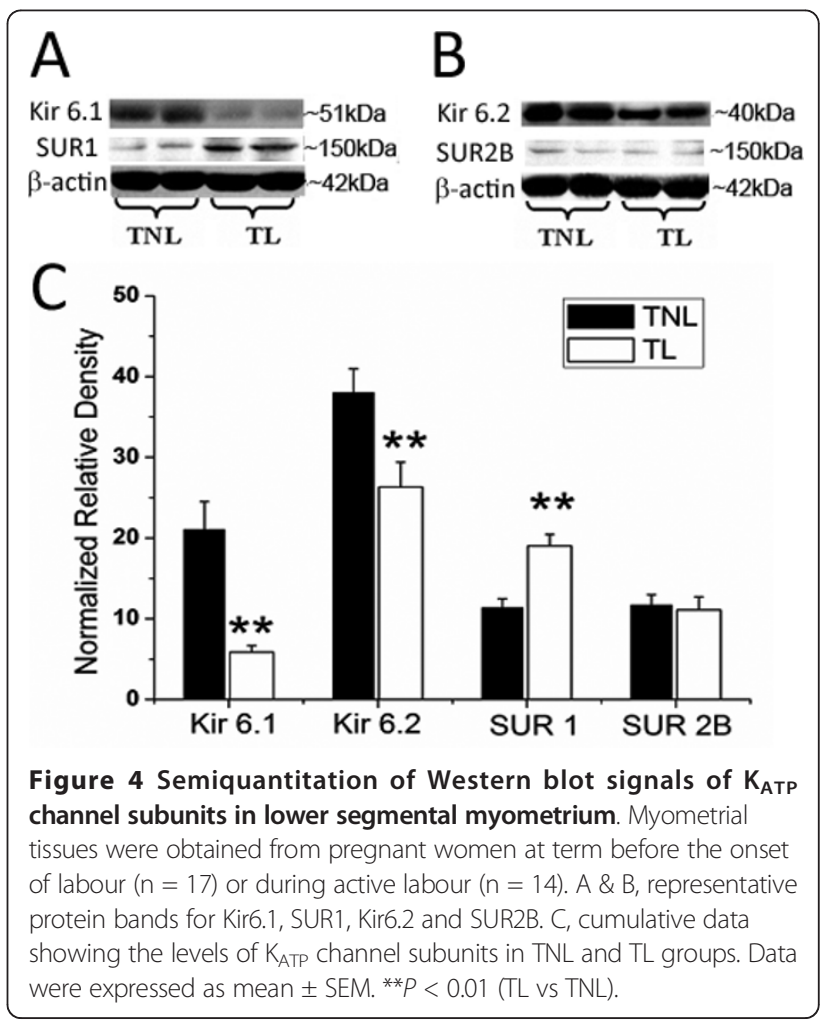




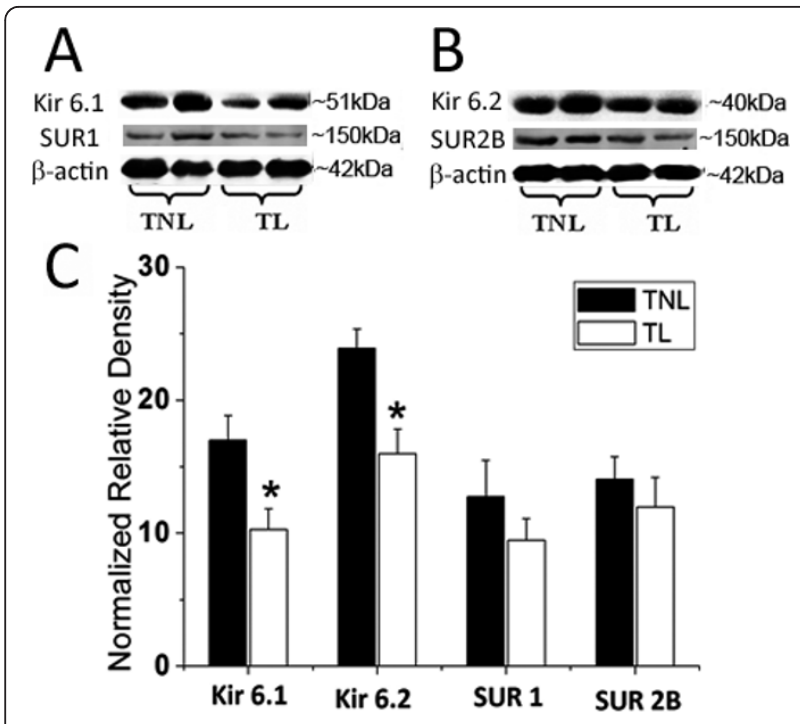

Figure 5 Semiquantitation of Western blot signals of $\mathrm{K}_{\mathrm{ATP}}$ channel subunits in upper segmental myometrium.

Myometrial tissues were obtained from pregnant women at term before the onset of labour $(n=7)$ or during labour $(n=4)$. A \& B, representative protein bands for Kir6.1, SUR1, Kir6.2 and SUR2B. C, cumulative data showing the levels of $K_{\text {ATP }}$ channel subunits in TNL and TL groups. Data were expressed as mean \pm SEM. ${ }^{*} P<$ 0.05 (TL vs TNL).

of human myometrium [30]. In the present study, we also found that diazoxide inhibits the spontaneous contractility of human pregnant myometrium. Taken together, our data suggest that subtypes of $\mathrm{K}_{\mathrm{ATP}}$ channel in pregnant human myometrium might be Kir6.1-SUR1, Kir6.1SUR2B, Kir6.2-SUR2B and Kir6.2-SUR1.

Longo et al [31] reported that a $\mathrm{K}_{\mathrm{ATP}}$ opener inhibited oxytocin-induced contractions in pregnant human myometrium. Sawada et al [32] demonstrated that overexpression of $\mathrm{K}_{\mathrm{ATP}}$ subunits Kir.6.1 and SUR2B contributes to an inhibition of oxytocin-induced uterus contractions in late pregnant rats. The present study found that the relaxatory effects of $\mathrm{K}_{\mathrm{ATP}}$ channel opener were decreased in TL strip compared with TNL myometrium. Thus, it is suggested that a decrease in the expression of $K_{\text {ATP }}$ channels may facilitate enhanced contractility of the myometrium after onset of parturition.

A number of studies have demonstrated differential expression of contraction-associated proteins (CAPs) such as connexin- 43 and prostaglandin receptors in US and LS myometrium after onset of labour [33-35]. However, some studies reported that the expression pattern of some CAPs in US and LS during labour are similar $[34,36,37]$. Prior studies have shown no differences in contractility between US and LS myometrium [38], which is supported by our own results on the BK channel [17]. In the present study, we found that the modulatory receptor subunit SUR1 was up-regulated in LS, but not in US, after onset of labour, suggesting that the $\mathrm{K}_{\mathrm{ATP}}$ function may differ between LS and US with the onset of labour.

\section{Conclusions}

Our results indicate that $\mathrm{K}_{\mathrm{ATP}}$ channel subunit Kir6.1, Kir6.2, SUR1 and SUR2B are predominately localized to myometrial cells in human pregnant uterus. The downregulation of $\mathrm{K}_{\mathrm{ATP}}$ channel subunit Kir6.1, Kir6.2 expression in myometrium may contribute to the enhanced uterine contractility associated with onset of labour.

\section{Acknowledgements}

The authors wish to thank the nursing and medical staff of the delivery suite as well as the patients at Changhai Hospital and Navy General Hospital for their participation. This work is supported by National Natural Science Foundation of China No. 30811120433 and No. 30971090, Science and Technology Commission of Shanghai Municipals (09XD1405600) and the China-CIHR/NSFC-IHDCYH program.

\section{Author details}

'Department of Physiology, Second Military Medical University, Shanghai 200433, China. ${ }^{2}$ Department of Gynecology and Obstetric, Navy General Hospital, Beijing 10037, China. ${ }^{3}$ Department of Gynecology and Obstetric, Changhai Hospital, Second Military Medical University, Shanghai 200433, China. ${ }^{4}$ Departments of Obstetrics and Gynecology, Pediatrics and Physiology, University of Alberta, Edmonton T6G 2 S, Canada.

\section{Authors' contributions}

CX performed Western blot analysis and immunohistochemistry experiments and analyzed the data. XY performed the tension study experiments. LG participated in Western blot and immunohistochemistry experiments as well as data analysis. $\mathrm{LZ}, \mathrm{RH}$ and $\mathrm{NH}$ recruited patients and organized the collection of tissues. DMO participated in manuscript preparation. XN conceived of the study, participated in its design, coordination and wrote the manuscript. All authors read and approved the final manuscript.

\section{Competing interests}

The authors declare that they have no competing interests.

Received: 30 July 2010 Accepted: 21 March 2011

Published: 21 March 2011

\section{References}

1. Challis JRG, Matthews SG, Gibb W, Lye SJ: Endocrine and paracrine regulation of birth at term and preterm. Endocr Rev 2000, 21(5):514-550.

2. Havelock JC, Keller P, Muleba N, Mayhew BA, Casey BM, Rainey WE, Word RA: Human myometrial gene expression before and during parturition. Biol Reprod 2005, 72(3):707-719.

3. Bukowski R, Hankins GD, Saade GR, Anderson GD, Thornton S: Laborassociated gene expression in the human uterine fundus, lower segment, and cervix. PLOS Med 2006, 3(6):e169.

4. Khan RN, Matharoo-Ball B, Arulkumaran S, Ashford ML: Potassium channels in the human myometrium. Exp Physiol 2001, 86(2):255-264.

5. Brainard AM, Korovkina VP, England SK: Potassium channels and uterine function. Semin Cell Dev Biol 2007, 18(3):332-339.

6. Teramoto N: Physiological roles of ATP-sensitive $\mathrm{K}+$ channels in smooth muscle. J Physiol 2006, 572(Pt 3):617-624.

7. Inagaki N, Gonoi T, Clement JPt, Namba N, Inazawa J, Gonzalez G, AguilarBryan L, Seino S, Bryan J: Reconstitution of IKATP: an inward rectifier subunit plus the sulfonylurea receptor. Science 1995, 270(5239):1166-1170.

8. Inagaki N, Gonoi T, Clement JP, Wang CZ, Aguilar-Bryan L, Bryan J, Seino S: A family of sulfonylurea receptors determines the pharmacological properties of ATP-sensitive K+ channels. Neuron 1996, 16(5):1011-1017. 
9. Aguilar-Bryan L, Clement JPt, Gonzalez G, Kunjilwar K, Babenko A, Bryan J: Toward understanding the assembly and structure of KATP channels. Physiol Rev 1998, 78(1):227-245.

10. Isomoto S, Kondo C, Yamada M, Matsumoto S, Higashiguchi O, Horio Y, Matsuzawa $Y$, Kurachi $Y$ : A novel sulfonylurea receptor forms with BIR (Kir6.2) a smooth muscle type ATP-sensitive K+ channel. J Biol Chem 1996, 271(40):24321-24324.

11. Morrison JJ, Ashford ML, Khan RN, Smith SK: The effects of potassium channel openers on isolated pregnant human myometrium before and after the onset of labor: potential for tocolysis. Am J Obstet Gynecol 1993, 169(5):1277-1285.

12. Cheuk JM, Hollingsworth M, Hughes SJ, Piper IT, Maresh MJ: Inhibition of contractions of the isolated human myometrium by potassium channel openers. Am J Obstet Gynecol 1993, 168(3 Pt 1):953-960.

13. Quayle JM, Nelson MT, Standen NB: ATP-sensitive and inwardly rectifying potassium channels in smooth muscle. Physiol Rev 1997, 77(4):1165-1232.

14. Chien EK, Zhang Y, Furuta H, Hara M: Expression of adenosine triphosphate-sensitive potassium channel subunits in female rat reproductive tissues: overlapping distribution of messenger ribonucleic acid for weak inwardly rectifying potassium channel subunit 6.1 and sulfonylurea-binding regulatory subunit 2. Am J Obstet Gynecol 1999, 180(5):1121-1126.

15. Curley M, Cairns MT, Friel AM, McMeel OM, Morrison JJ, Smith TJ: Expression of mRNA transcripts for ATP-sensitive potassium channels in human myometrium. Mol Hum Reprod 2002, 8(10):941-945.

16. Pritchard JA, MacDonald PC, Gant NF: The placenta and fetal membranes and maternal adaptation to pregnancy. Williams' obstetrics. 17 edition. Stamford, CT: Appleton Century Crofts; 1985, 295-320.

17. Gao L, Cong B, Zhang L, Ni X: Expression of the calcium-activated potassium channel in upper and lower segment human myometrium during pregnancy and parturition. Reprod Biol Endocrinol 2009, 7:27.

18. Cong B, Zhang L, Gao L, Ni X: Reduced expression of CRH receptor type 1 in upper segment human myometrium during labour. Reprod Biol Endocrinol 2009, 7(1):43.

19. Yunoki T, Teramoto $N$, Ito $Y$ : Functional involvement of sulphonylurea receptor (SUR) type 1 and $2 \mathrm{~B}$ in the activity of pig urethral ATP-sensitive K+ channels. Br J Pharmacol 2003, 139(3):652-660.

20. Brayden JE: Potassium channels in vascular smooth muscle. Clin Exp Pharmacol Physiol 1996, 23(12):1069-1076.

21. Cui Y, Tran S, Tinker A, Clapp LH: The molecular composition of K(ATP) channels in human pulmonary artery smooth muscle cells and their modulation by growth. Am J Respir Cell Mol Biol 2002, 26(1):135-143.

22. Quayle JM, Bonev AD, Brayden JE, Nelson MT: Calcitonin gene-related peptide activated ATP-sensitive $\mathrm{K}+$ currents in rabbit arterial smooth muscle via protein kinase A. J Physiol 1994, 475(1):9-13.

23. Ding WG, He LP, Omatsu-Kanbe M, Kitasato $H$ : A possible role of the ATPsensitive potassium ion channel in determining the duration of spikebursts in mouse pancreatic beta-cells. Biochim Biophys Acta 1996, 1279(2):219-226.

24. Aguilar-Bryan L, Bryan J: Molecular Biology of Adenosine TriphosphateSensitive Potassium Channels. Endocr Rev 1999, 20(2):101-135.

25. Ashcroft FM, Gribble FM: Correlating structure and function in ATPsensitive K+ channels. Trends Neurosci 1998, 21(7):288-294.

26. Yamada M, Isomoto $S$, Matsumoto $S$, Kondo $C$, Shindo $T$, Horio $Y$, Kurachi $Y$ : Sulphonylurea receptor $2 \mathrm{~B}$ and Kir6.1 form a sulphonylurea-sensitive but ATP-insensitive K+ channel. J Physiol 1997, 499(Pt 3):715-720.

27. Yokoshiki H, Sunagawa M, Seki T, Sperelakis N: ATP-sensitive K+ channels in pancreatic, cardiac, and vascular smooth muscle cells. Am J Physiol 1998, 274(1 Pt 1):C25-37.

28. Teramoto N, McMurray G, Brading AF: Effects of levcromakalim and nucleoside diphosphates on glibenclamide-sensitive $\mathrm{K}+$ channels in pig urethral myocytes. Br J Pharmacol 1997, 120(7):1229-1240.

29. Teramoto N, Yunoki T, Tanaka K, Takano M, Masaki I, Yonemitsu Y, Sueishi K, Ito $Y$ : The effects of caffeine on ATP-sensitive $K(+)$ channels in smooth muscle cells from pig urethra. Br J Pharmacol 2000, 131(3):505-513.

30. Cordeaux Y, Missfelder-Lobos H, Charnock-Jones DS, Smith GC: Stimulation of contractions in human myometrium by serotonin is unmasked by smooth muscle relaxants. Reprod Sci 2008, 15(7):727-34.

31. Longo M, Jain V, Vedernikov YP, Hankins GDV, Garfield RE, Saade GR: Effects of L-type Ca2+-channel blockade, K+ATP-channel opening and nitric oxide on human uterine contractility in relation to gestational age and labour. Mol Hum Reprod 2003, 9(3):159-164.

32. Sawada K, Morishige K, Hashimoto K, Tasaka K, Kurachi H, Murata Y, Kurachi Y: Gestational change of K+ channel opener effect is correlated with the expression of uterine KATP channel subunits. Eur J Obstet Gynecol Reprod Biol 2005, 122(1):49-56.

33. Sparey C, Robson SC, Bailey J, Lyall F, Europe-Finner GN: The differential expression of myometrial connexin-43, cyclooxygenase- 1 and -2, and Gs alpha proteins in the upper and lower segments of the human uterus during pregnancy and labor. J Clin Endocrinol Metab 1999, 84:1705-1710.

34. Bukowski R, Hankins GD, Saade GR, Anderson GD, Thornton S: Laborassociated gene expression in the human uterine fundus, lower segment, and cervix. PLOS Med 2006, 3:e169.

35. Grigsby PL, Sooranna SR, Adu-Amankwa B, Pitzer B, Brockman DE, Johnson MR, Myatt L: Regional expression of prostaglandin E2 and F2alpha receptors in human myometrium, amnion, and choriodecidua with advancing gestation and labor. Biol Reprod 2006, 75:297-305.

36. Sooranna SR, Grigsby PL, Engineer N, Liang Z, Sun K, Myatt L, Johnson MR: Myometrial prostaglandin E2 synthetic enzyme mRNA expression: spatial and temporal variations with pregnancy and labour. Mol Hum Reprod 2006, 12:625-631.

37. Havelock JC, Keller P, Muleba N, Mayhew BA, Casey BM, Rainey WE, Word RA: Human myometrial gene expression before and during parturition. Biol Reprod 2005, 72:707-719.

38. Luckas MJ, Wray S: A comparison of the contractile properties of human myometrium obtained from the upper and lower uterine segments. BJOG 2000, 107(10):1309-1311.

doi:10.1186/1477-7827-9-35

Cite this article as: Xu et al.: Expression of ATP-sensitive potassium channels in human pregnant myometrium. Reproductive Biology and Endocrinology 2011 9:35.

\section{Submit your next manuscript to BioMed Central and take full advantage of:}

- Convenient online submission

- Thorough peer review

- No space constraints or color figure charges

- Immediate publication on acceptance

- Inclusion in PubMed, CAS, Scopus and Google Scholar

- Research which is freely available for redistribution

Submit your manuscript at www.biomedcentral com/submit
C) Biomed Central 